\title{
Comparative uterine gene expression analysis after dioxin and estradiol administration
}

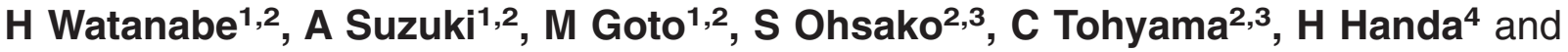 \\ T Iguchi 1,2 \\ ${ }^{1}$ Center for Integrative Bioscience, Okazaki National Research Institutes, 5-1 Higashiyama, Myodaiji, Okazaki 444-8585, Japan \\ ${ }^{2}$ Core Research for Evolution Science and Technology (CREST), Japanese Science and Technology Corporation, Kawaguchi 332-0012, Japan \\ ${ }^{3}$ Environmental Health Sciences Division, National Institute for Environmental Studies, Onogawa, Tsukuba 305-8506, Japan \\ ${ }^{4}$ Frontier Collaborative Research Center, Tokyo Institute of Technology, 4259 Nagatsuta-cho, Yokohama, Kanagawa 226-8503, Japan
}

(Requests for offprints should be addressed to T Iguchi; Email: taisen@nibb.ac.jp)

\begin{abstract}
The environmental pollutant 2,3,7,8-tetrachlorodibenzo-p-dioxin (TCDD) adversely affects many organisms. TCDD exposure is known to be associated with abnormal development, hepatotoxicity and endocrine effects. It has also been reported to have antiestrogenic activity in addition to estrogenic activity. In order to clarify the effects of TCDD in the uterus, we evaluated the patterns of gene expression after TCDD and estradiol administration. Of the 10000 arrayed genes, only a few were affected by both estradiol and TCDD. Although the subset of genes that responded to estrogen was also activated by TCDD, the response to TCDD was more limited than that observed in response to estradiol. Therefore, according to our analysis of gene expression patterns, TCDD had partial and weak estrogenic activity in the uterus.
\end{abstract}

Journal of Molecular Endocrinology (2004) 33, 763-771

\section{Introduction}

The environmental pollutant, 2,3,7,8tetrachlorodibenzo- $p$-dioxin (TCDD), is an aromatic hydrocarbon that has a long biologic half-life and accumulates in animals, especially those higher in the food chain. TCDD has adverse effects on the immune system, liver, embryo, endocrine system and skin, but actual mechanisms that explain the effects are largely unknown. In the case of the reproductive tract, it has been reported that TCDD exposure is associated with an increase in endometriosis (Gibbons 1993, Rier et al. 1993, Bois \& Eskenazi 1994, Cummings et al. 1996, Mayani et al. 1997, Rier \& Foster 2002) and mammary cancer (Manz et al. 1991, Brown et al. 1998). On the other hand, other epidemiologic studies have reported that TCDD exposure can reduce mammary and uterine cancer in rats (Kociba et al. 1978) and humans (Bertazzi et al. 2001), suggesting that the effects of TCDD may be exerted through multiple mechanisms.
The effects of TCDD on the reproductive tract and, more specifically, comparisons of the effects of TCDD and estrogen have been reported previously. For example, the antiestrogenic effects of TCDD are well documented (Gallo et al. 1986, Gierthy et al. 1987, Romkes et al. 1987, Safe et al. 1991), and some molecular mechanisms of toxicity have been proposed (Krishnan et al. 1995, Wormke et al. 2003). Conversely, estrogenic effects of TCDD have also been reported (Nesaretnam et al. 1996, Abdelrahim et al. 2003).

TCDD binds to an aryl hydrocarbon receptor $(\mathrm{AhR})$ that is associated with heat-shock protein 90 . After the ligand binds, AhR dissociates from the heat-shock protein to form a heteromeric complex with AhR nuclear translator (ARNT). The complex then moves into the nucleus and binds to a xenobiotic response element (XRE) to activate the transcription of the TCDD response gene. The ligand-dependent behavior of $\mathrm{AhR}$ is similar to the estrogen receptor (ER) to some extent. When estrogen binds to the ER, the ER binds to the 
estrogen-response element (ERE) to activate the transcription of estrogen-response genes. Two models are proposed to explain the estrogenic effect of TCDD. One is direct binding of TGDD to ER (Nesaretnam et al. 1996) and the other is ligand-dependent protein-protein interaction of $\mathrm{AhR}$ and ER, which has been demonstrated with 3-methylcholanthrene (Ohtake et al. 2003).

In the present study, we used DNA microarray analysis to investigate the estrogenic activity of TCDD. Accordingly, we determined the effects of TCDD and estrogen on gene expression and compared their gene expression patterns. By this approach, we estimated the estrogenic effects of TCDD.

\section{Materials and methods}

\section{Animals}

Female C57/BL6/J mice were purchased from SLC, Inc. (Tokyo, Japan), housed under a 12-h light:dark cycle and given free access to food and water. Mice were ovariectomized at 8 weeks of age and, 2 weeks later, either sesame oil vehicle (Nakarai Tesque, Kyoto, Japan) or test material was administered to the animals. Whole uteri $(n=4)$ were collected $6 \mathrm{~h}$ after dosing. The doses of $17 \beta$-estradiol (E2) (Sigma, Sigma-Aldrich Japan, Tokyo, Japan) were $0,0 \cdot 05,0 \cdot 5,5 \cdot 0$ and $50 \mu \mathrm{g} / \mathrm{kg}$ body weight (b.w.). The doses of TCDD (Cambridge Isotope Laboratory, Andover, MA, USA) were $0,1.0$ and $10 \mu \mathrm{g} / \mathrm{kg}$ b.w. Our institutional animal care committee approved all animal experiments.

\section{Immunohistochemistry}

Uterine tissue sections $(4 \mu \mathrm{m})$ were prepared and incubated with anti-ER, anti-AhR or anti-ARNT antibodies. Staining was performed with a Histofine kit (Nichirei, Tokyo, Japan) according to the manufacturer's protocol. Briefly, deparaffinized and rehydrated tissue sections were boiled twice in citrate buffer $(10 \mathrm{mM}$ citrate, $\mathrm{pH} 6 \cdot 0)$ for $5 \mathrm{~min}$ and pretreated with $3 \%$ hydrogen peroxide for $10 \mathrm{~min}$. The anti-ER (H-184), anti-AhR (M-20) and anti-ARNT (C-19) antibodies (Santa Cruz Biotechnologies, Santa Gruz, CA, USA) were incubated with the tissue sections at $4{ }^{\circ} \mathrm{C}$ overnight. For immunodetection, the sections were incubated with a second antibody conjugated with peroxidase for $10 \mathrm{~min}$ and developed with 3,3'-diaminobenzidine.

\section{DNA microarray analysis}

Total uterine RNA was extracted with TRIzol (Invitrogen, Tokyo, Japan) and purified with the RNeasy minikit (Qiagen, Tokyo, Japan). Total RNA quality was examined with a Bioanalyzer 2100 (Agilent Japan, Tokyo, Japan). Purified RNA was processed according to the manufacturer's protocol to prepare the labeled cRNAs, which were hybridized to the mouse genome U74 array (Affymetrix Japan, Tokyo, Japan). Hybridization, washing and scanning were performed according to the manufacturer's protocol.

\section{Data analysis}

Scanned data were analyzed with GeneChip Suit Analysis Software ver.5·0 (Affymetrix Japan, Tokyo, Japan) to obtain the average intensity of each cell corresponding to each oligonucleotide probe. The averaged fluorescence intensity (2500) of each probe was further analyzed by dChip, a model-based expression-analysis program (Li \& Wong 2001), and expression levels were estimated. The PM-only model was used for the analysis, and the estimated values were transferred to the GeneSpring software program (Silicon Genetics, Redwood City, CA, USA) and analyzed. To calculate changes in expression, genes for which average expression levels were more than 1000 fluorescence intensity units under at least one experimental condition were selected, and the average expression values of the treated samples were divided by those from control samples.

\section{Quantitative real-time PCR}

Total RNA was purified as described above. cDNA was synthesized from purified total RNA with Superscript II RT(-) (Invitrogen, Tokyo, Japan), and random primers at $42{ }^{\circ} \mathrm{C}$ for $60 \mathrm{~min}$. PGR reactions were performed in the Prism 7000 sequence detector (Applied Biosystems Japan, Tokyo, Japan) with SYBR-Green PGR core reagents (Applied Biosystems Japan, Tokyo, Japan) in the presence of appropriate primers, according to the manufacturer's instructions. The primers 


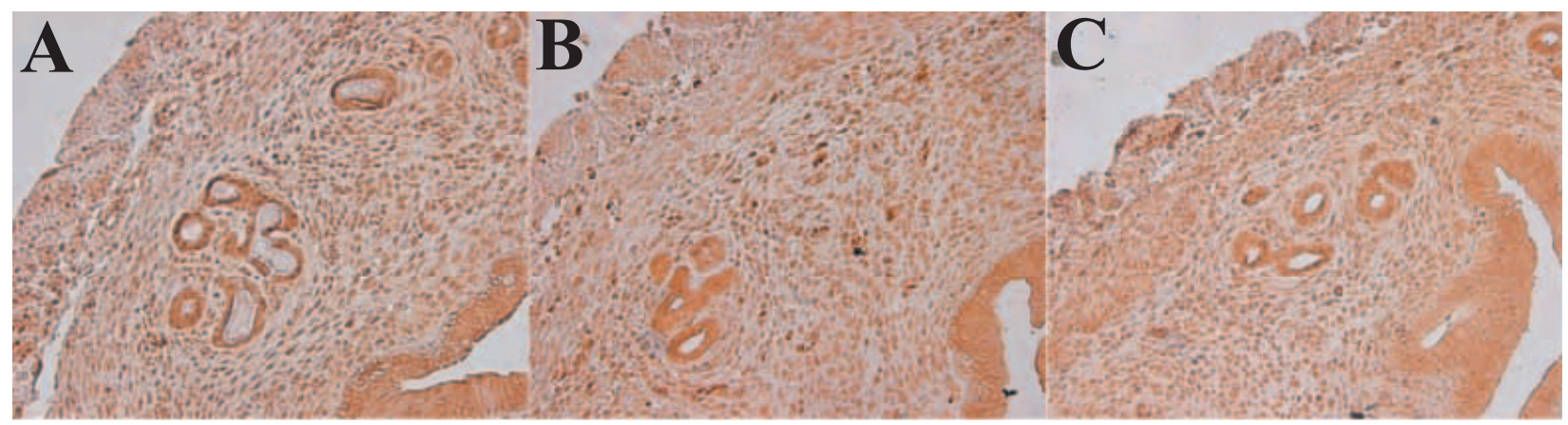

Figure 1 Immunolocalization of DNA-binding transcription factors. Tissue distributions of ER, AhR and ARNT in uterus were examined by immunohistochemistry. Rather intense signals were detected in epithelial tissues. A clear difference in staining level between the myometrium and stroma was not observed for ER, AhR and ARNT. Magnification, $\times 400$ ER (A), AhR (B) and ARNT (C).

were chosen to amplify short PGR products of less than 100 base pairs, and their sequences are as follows:

- NM_007636 (chaperonin subunit 2; Cct2) CGCTGCTGGCGTCATG, TGACAAGAG CGAGGCGCT

- NM_019768 (mortality factor 4 like 2; Morf4l 2) AGCTGGTTGGCAGCGAAA, CAGAGCGACGTCGCGATCT

- NM_009455 (ubiquitin-conjugating enzyme E2E 1; Ube2e1) GCTATGTGGGATGAG GATTCG, TCTCGGTCTGCTGGTTGGA

- NM_007479 (ADP-ribosylation factor 4; Arf4) CGTCGTTTTGACGGTCAAGTG, AACA GGCGGGAGAAGAGAGA

- NM_011045 (proliferating cell nuclear antigen; Pcna) GCGGAGAGGGTTGGTAG TTG, GCGGATTCACGATGGAGAA

- NM_009505 (vascular endothelial growth factor A; Vegfa) ACATCTTCAAGCGGTCG TGTGT, GTCGAGGGCTTCATCGTTACA

- NM_012053 (ribosome L8, Rplo, used as control) ACAGAGGGGTTGTTGGTGT TG, GAGGAGTTCGTGTTTGGGTTGT.

Each PCR amplification was performed in triplicate in the following conditions: $2 \mathrm{~min}$ at $50{ }^{\circ} \mathrm{C}$ and $10 \mathrm{~min}$ at $95^{\circ} \mathrm{C}$, followed by a total of 40 two-temperature cycles $\left(15 \mathrm{~s}\right.$ at $95^{\circ} \mathrm{C}$ and $1 \mathrm{~min}$ at $60^{\circ} \mathrm{C}$ ). Model 7000 software was used to construct amplification plots from extensionphase fluorescent emission data collected during PCR amplification. Threshold $(\mathrm{C} \tau)$ values were calculated by determining the point at which fluorescence exceeds a threshold limit.
Gene expression levels were normalized to the expression levels of L8 mRNA (U67771), and changes in concentration were calculated. Gel electrophoresis and melting curve analyses were performed to confirm correct amplicon size and the absence of nonspecific bands. Quantification of mRNAs was repeated three times with independent mice, and average levels of change were calculated.

\section{Results}

\section{Expression of AhR in uterus}

To examine the effects of TCDD and estradiol on uterine gene expression, we first examined the
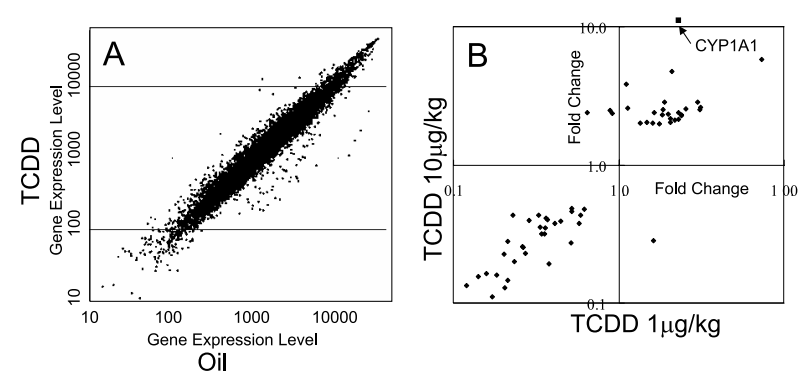

Figure 2 Gene expression changes induced by TCDD. Uterine gene expression after TCDD treatment was examined by DNA microarray. (A) Scatter plot of gene expression levels after TCDD exposure (y-axis) versus control gene expression levels (indicated by oil, $x$-axis). Gene expression levels correspond to the fluorescence intensity of the scanned DNA microarray. (B) Changes in gene expression levels upon treatment with $1 \mu \mathrm{g} / \mathrm{kg}$ (x-axis) or $10 \mu \mathrm{g} / \mathrm{kg}$ (y-axis) TCDD. The plot corresponding to cytochrome P450 1A1 gene is indicated as 'CYP1A1'. 
Table 1 Changes in TCDD activated genes in the uterus. Changes in gene expression levels based on oil treatment were calculated for both doses $(1$ and $10 \mu \mathrm{g} / \mathrm{kg}$ ). Only the genes that were activated more than two-fold by $10 \mu \mathrm{g} / \mathrm{kg}$ of TCDD are indicated. Genes that were also activated more than 1.5-fold by estradiol (see also Figure 4) are indicated in bold.

\begin{tabular}{|c|c|c|c|}
\hline \multirow{2}{*}{$\begin{array}{l}\text { Genbank } \\
\text { Accession }\end{array}$} & \multicolumn{3}{|c|}{ TCDD $(\mu g / k g)$} \\
\hline & 0 & 1 & 10 \\
\hline K02588 & $1 \cdot 0$ & $2 \cdot 3$ & $10 \cdot 3$ \\
\hline X13060 & 1.0 & $10 \cdot 8$ & $7 \cdot 8$ \\
\hline Y14660 & $1 \cdot 0$ & $7 \cdot 4$ & $5 \cdot 8$ \\
\hline M81445 & $1 \cdot 0$ & $2 \cdot 1$ & $4 \cdot 7$ \\
\hline M60523 & 1.0 & $1 \cdot 1$ & $3 \cdot 8$ \\
\hline M16360 & $1 \cdot 0$ & $3 \cdot 0$ & $2 \cdot 8$ \\
\hline D16333 & $1 \cdot 0$ & 1.9 & $2 \cdot 8$ \\
\hline M17818 & $1 \cdot 0$ & $3 \cdot 1$ & $2 \cdot 6$ \\
\hline M95604 & $1 \cdot 0$ & $1 \cdot 1$ & $2 \cdot 6$ \\
\hline M69260 & $1 \cdot 0$ & $2 \cdot 6$ & 2.5 \\
\hline X00945 & $1 \cdot 0$ & $3 \cdot 1$ & 2.5 \\
\hline X99347 & $1 \cdot 0$ & 1.9 & 2.5 \\
\hline M31885 & $1 \cdot 0$ & 0.9 & 2.5 \\
\hline M95200 & $1 \cdot 0$ & 0.6 & 2.4 \\
\hline D10627 & $1 \cdot 0$ & 1.6 & $2 \cdot 4$ \\
\hline AB009275 & 1.0 & $2 \cdot 3$ & $2 \cdot 4$ \\
\hline AB015140 & $1 \cdot 0$ & 0.9 & $2 \cdot 3$ \\
\hline X66091 & $1 \cdot 0$ & $2 \cdot 0$ & $2 \cdot 3$ \\
\hline X60452 & 1.0 & 2.4 & $2 \cdot 3$ \\
\hline X91656 & $1 \cdot 0$ & 1.8 & $2 \cdot 3$ \\
\hline M12347 & $1 \cdot 0$ & $2 \cdot 4$ & $2 \cdot 3$ \\
\hline X92665 & 1.0 & $2 \cdot 1$ & $2 \cdot 2$ \\
\hline X17320 & 1.0 & $2 \cdot 3$ & $2 \cdot 1$ \\
\hline AB023564 & $1 \cdot 0$ & $2 \cdot 2$ & $2 \cdot 1$ \\
\hline X99963 & 1.0 & 1.5 & $2 \cdot 0$ \\
\hline X57800 & $1 \cdot 0$ & $2 \cdot 1$ & $2 \cdot 0$ \\
\hline AB022156 & $1 \cdot 0$ & 1.6 & $2 \cdot 0$ \\
\hline D87901 & 1.0 & 1.8 & $2 \cdot 0$ \\
\hline
\end{tabular}

\section{Definition}

cytochrome; cytochrome P450

LINE repetitive sequence; repetitive sequence; serum albumin fabp/ gene; fatty acid binding protein; L-FABP connexin; transmembrane protein growth factor-inducible protein; helix-loop-helix protein major urinary protein; tissue specific gene coproporphyrinogen oxidase; coproporphyrinogenase urinary protein mesoderm; zinc-finger protein lipocortin 1 protease inhibitor LBP gene; LPS-binding protein helix-loop-helix DNA binding protein regulator vegfagene; vascular endothelial growth factor zinc finger protein matrin3 AhR repressor alternative splicing factor; $A S F$ gene; RNA-binding protein cytochrome P450; cytochrome P450 IIIA splicing factor; SRp20 gene actin; alpha-actin UbcM3 gene; ubiquitin-conjugating enzyme antigen; pcp4 gene type I peroxiredoxin rhoB gene Pcna gene; proliferating cell nuclear antigen chaperonin containing TCP-1 beta subunit Arf4 gene; ADP-ribosylation factor spatial expression pattern of $\mathrm{AhR}$ and compared it with the expression pattern of ER and ARNT. Immunohistochemistry localized AhR and ARNT within the uterine tissues and showed that the expression pattern of AhR was very similar to that of the transcription factors ER and ARNT (Fig. 1). All three proteins were expressed to a greater degree in luminal and glandular epithelium than in other tissues, and clear differences in expression levels could not be observed between stroma and myometrium.

\section{Effect of TCDD on uterine gene expression}

To profile uterine genes affected by TCDD, mice were ovariectomized to eliminate the effect of endogenous estrogen; 2 weeks later, they were treated with $10 \mu \mathrm{g} / \mathrm{kg}$ TCDD. Six hours after treatment, uteri were removed and RNA was isolated. We examined the expression of about 10000 genes by DNA microarray analysis. As shown in Fig. 2A, the scatter plot of gene expressions treated by TCDD versus control showed a diagonal line, indicating that most gene expression levels did not change to a large extent, and that there was little bias during data acquisition and analysis. As a result, it was found that 28 annotated genes were activated and 20 annotated genes were repressed more than twofold after filtering the data (see Materials and methods). Lists of the activated and repressed genes are provided in Tables 1 and 2 respectively.

To determine whether the genes responded to TCDD in a dose-dependent manner, we treated additional mice with $1 \mu \mathrm{g} / \mathrm{kg}$ TCDD, monitored changes in their gene expression and compared the 
Table 2 Changes in TCDD repressed genes in the uterus. Changes in gene expression levels based on oil treatment were calculated for both doses $(1 \mu / \mathrm{kg}$ and $10 \mu \mathrm{g} / \mathrm{kg})$. Only the genes that were repressed more than two-fold are indicated. Genes related to immunoglobulin are marked with asterisks.

\begin{tabular}{|c|c|c|c|c|}
\hline \multirow{2}{*}{$\begin{array}{l}\text { Genbank } \\
\text { Accession }\end{array}$} & \multicolumn{3}{|c|}{ TCDD $(\mu \mathrm{g} / \mathrm{kg})$} & \multirow[b]{2}{*}{ Definition } \\
\hline & 0 & 1 & 10 & \\
\hline L43568 & $1 \cdot 0$ & 0.5 & 0.5 & *antigen, B-cell receptor \\
\hline AB001607 & $1 \cdot 0$ & 0.6 & 0.5 & prostacyclin synthase \\
\hline X04673 & 1.0 & 0.5 & 0.5 & adipsin; inverted repeat; serine protease; tandem repeat \\
\hline M20497 & $1 \cdot 0$ & 0.6 & 0.4 & adipose fatty acid-binding protein; binding protein \\
\hline L04961 & 1.0 & 0.2 & 0.4 & inactive X-specific transcript \\
\hline X03505 & $1 \cdot 0$ & 0.3 & 0.4 & serum amyloid $A$ protein; serum protein \\
\hline X88903 & $1 \cdot 0$ & 0.4 & 0.4 & *light chain; variable region \\
\hline AJ006474 & 1.0 & 0.6 & 0.4 & ca3 gene; carbonic anhydrase; carbonic anhydrase III; promoter region \\
\hline D26090 & $1 \cdot 0$ & 0.4 & 0.3 & mCDC46; CDC46; mCDC46 protein; DNA replication \\
\hline L14553 & $1 \cdot 0$ & 0.3 & 0.3 & $\begin{array}{l}\text { *immunoglobulin light chain; monoclonal antibody; rearranged gene; variable } \\
\text { region }\end{array}$ \\
\hline 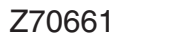 & $1 \cdot 0$ & 0.4 & 0.3 & *Ig kappa light chain; Ig light chain; immunoglobulin; joining region; variable region \\
\hline M12481 & $1 \cdot 0$ & 1.6 & $0 \cdot 3$ & beta-actin \\
\hline X67210 & $1 \cdot 0$ & 0.2 & 0.3 & "constant region; immunoglobulin; immunoglobulin heavy chain; variable region \\
\hline X00652 & $1 \cdot 0$ & 0.3 & 0.3 & *Ig kappa light chain; Ig light chain; immunoglobulin; joining region; variable region \\
\hline X16678 & $1 \cdot 0$ & 0.3 & 0.3 & *Ig kappa light chain; variable region; $V k$ gene \\
\hline X02468 & $1 \cdot 0$ & 0.3 & 0.2 & $\begin{array}{l}\text { *germ line; Ig heavy chain; immunoglobulin; variable region; variable region } \\
\text { subgroup VH-II }\end{array}$ \\
\hline M19681 & $1 \cdot 0$ & 0.2 & 0.2 & JE protein; cytokine \\
\hline M90766 & 1.0 & 0.2 & $0 \cdot 1$ & *immunoglobulin mu-chain; joining chain; polymeric IgM, IgA \\
\hline M80423 & $1 \cdot 0$ & 0.2 & $0 \cdot 1$ & ${ }^{*}$ C-region; immunoglobulin light chain; immunoglobulin mu-chain \\
\hline J00475 & $1 \cdot 0$ & 0.2 & 0.1 & $\begin{array}{l}{ }^{*} \mathrm{C} \text {-region; alternative splicing; germline; immunoglobulin heavy chain; } \\
\text { immunoglobulin-alpha }\end{array}$ \\
\hline
\end{tabular}

results to those from the $10 \mu \mathrm{g} / \mathrm{kg}$ dose (Fig. 2B). The cytochrome p450 1Al gene exhibited a dose-dependent activation pattern, as indicated by its location near the $\mathrm{y}$-axis on a plot of gene expression levels (designated CYP1A1 in Fig. 2B). On the other hand, the expression levels of many other genes plotted onto a nearly diagonal line indicated that these genes were not activated in a dose-dependent fashion at $1-10 \mu \mathrm{g} / \mathrm{kg}$. Many of the repressed genes generally exhibit immune system function, such as immunoglobulin chains and B-cell receptor antigen.

\section{Comparison of TCDD gene-activation pattern with estrogen effects}

To determine whether the effects of TGDD on uterine gene expression are similar to estradiol, we analyzed and compared the gene expression patterns after treatment with both agents. The genes that were activated or repressed more than twofold by either TCDD or estradiol at $6 \mathrm{~h}$ were selected for further analysis. The 575 selected genes, which included EST genes, were analyzed by hierarchic clustering (Fig. 3). According to the dendrogram, this activation pattern was divided into six primary clusters, as indicated in Table 3 (Fig. 3A-F, dendrogram is not shown).

Genes in cluster A were activated by both TCDD and estradiol, although the gene expression changes induced by TCDD were much smaller than those induced by estradiol. Average changes in response to TCDD were comparable to $0.5 \mu \mathrm{g} / \mathrm{kg}$ estradiol. Many genes clustered in B were activated only by estradiol, and not by TCDD. From this clustering analysis, the number of genes affected by both TCDD and estradiol was rather limited, and only a portion of estrogenactivated genes were weakly activated by TCDD.

DNA microarray analysis suggested that six of the TCDD-induced genes were activated more than twofold by estradiol. Three genes were confirmed to be activated more than $1 \cdot 5$-fold by both TCDD and estradiol by quantitative PCR, although the changes were not consistent with those observed on the DNA microarray (Fig. 4). 

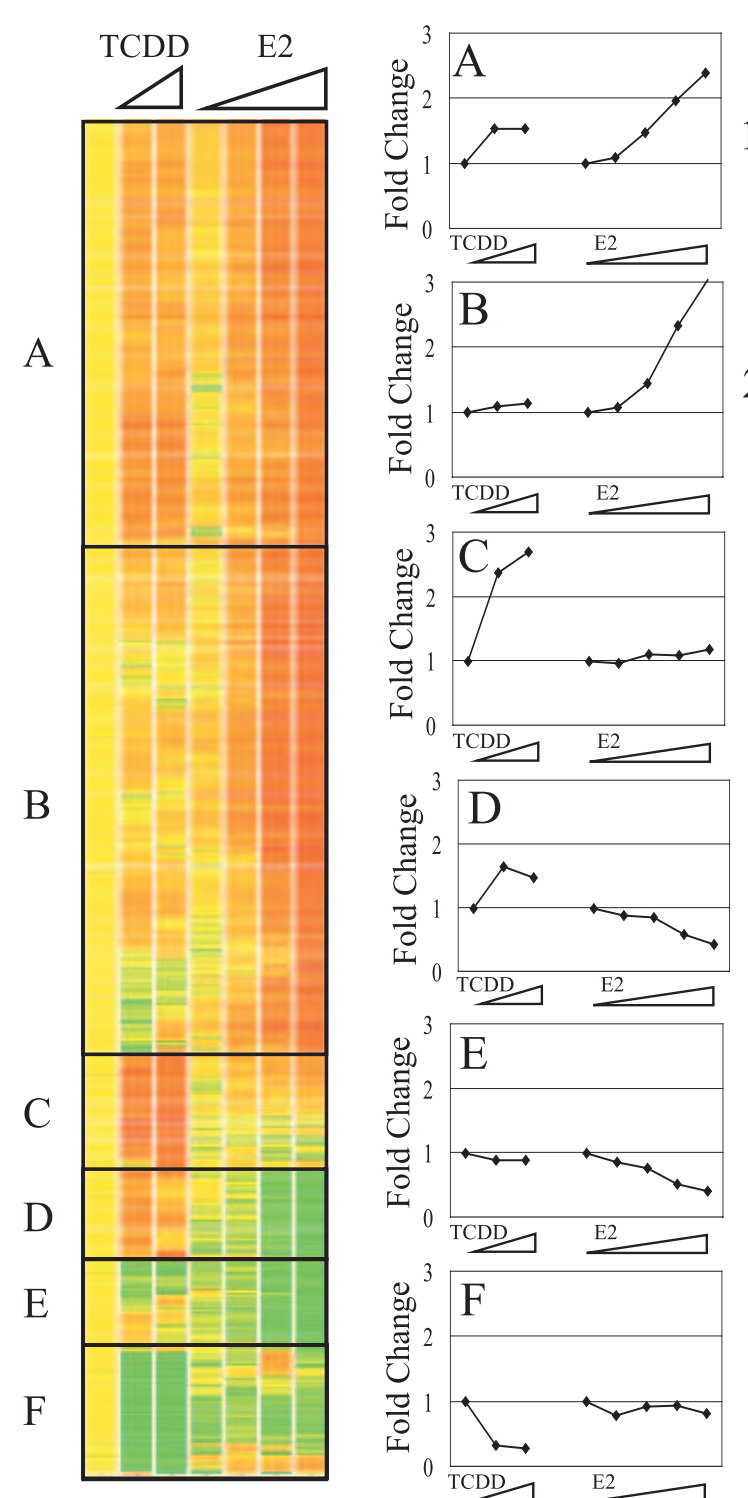

182

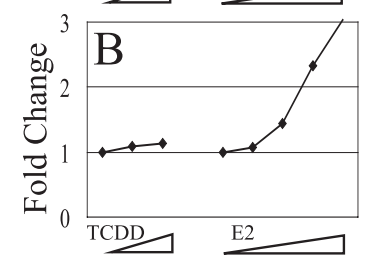

215
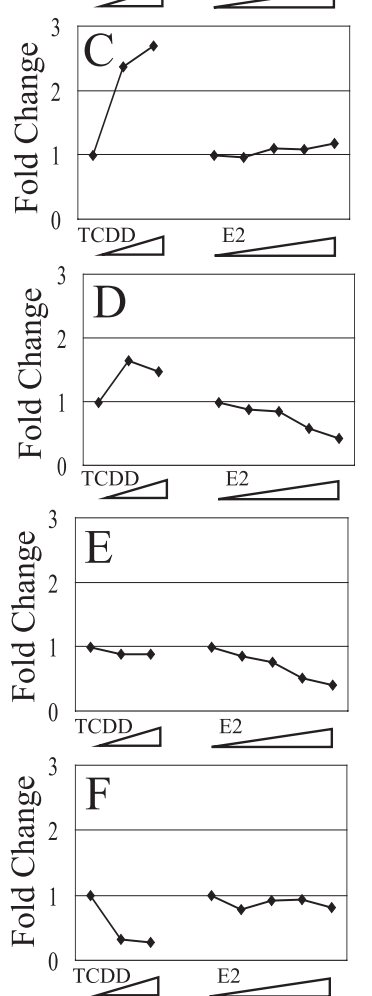

Figure 3 Distinct gene expression patterns after TCDD and estradiol (E2) administration. The genes that were activated more than twofold by either TCDD or estradiol were selected, and their expression patterns were analyzed by hierarchic clustering. According to the dendrogram (not shown), the expression patterns were divided into six classes $(\mathrm{A}-\mathrm{F})$. The average changes for each class are indicated on the right. The numbers indicate the number of genes classified into each class. Dose increments are indicated by triangles, which correspond to 0,1 and $10 \mu \mathrm{g} / \mathrm{kg}$ for TCDD, and $0.05,0.5,5$ and $50 \mu \mathrm{g} / \mathrm{kg}$ for estradiol (from left to right).
Table 3 Gene activation pattern of TCDD or E2 induced genes. Based on the result of hierarchical clustering, six clusters were found (Fig. 3). Averaged gene expression pattern in each cluster is indicated

\begin{tabular}{lllll} 
Cluster & & TCDD & & Estradiol \\
\cline { 1 - 1 } A & & Slightly activated & & Activated \\
B & & Not activated & & Activated \\
C & Mainly activated & & Not activated \\
D & Weakly activated & & Repressed \\
E & Not repressed & & Repressed \\
F & Repressed & & Not affected
\end{tabular}

These genes included vascular endothelial growth factor A (Vegfa, NM_009505), proliferating cell nuclear antigen (Pcna, NM_011045) and ADPribosylation factor 4 (Arf4, NM_007479) (Kim et al. 2003) (indicated in boldface in Table 1).

\section{Temporal changes in TCDD-induced genes in response to estrogen}

Since the number of genes activated by both TCDD and estradiol was rather small, we selected a gene set that was induced by TCDD at $6 \mathrm{~h}$ and examined its temporal activation pattern after estradiol treatment. If the kinetics of AhR are much slower than those of ER, gene activation through AhR may be slower than that through ER. In this case, even if the set of activated genes is similar, temporal expression patterns may differ, and genes activated by AhR at $6 \mathrm{~h}$ may be similar to those activated by ER at a much earlier time point. Although several TCDD-responsive genes were activated at $1-2 \mathrm{~h}$ by estradiol (Fig. 5A), some other genes were activated much later (Fig. 5B), and no time point was identified at which the majority of TCDD-responsive genes were activated simultaneously. This result indicates that the E2-affected genes and the TCDD-affected genes did not overlap temporally.

\section{Discussion}

\section{TCDD-affected genes}

To examine the estrogenic effects of TCDD, we used DNA microarray analysis to evaluate uterine gene expression after treatment with TCDD or estrogen. The number of TCDD-affected genes 


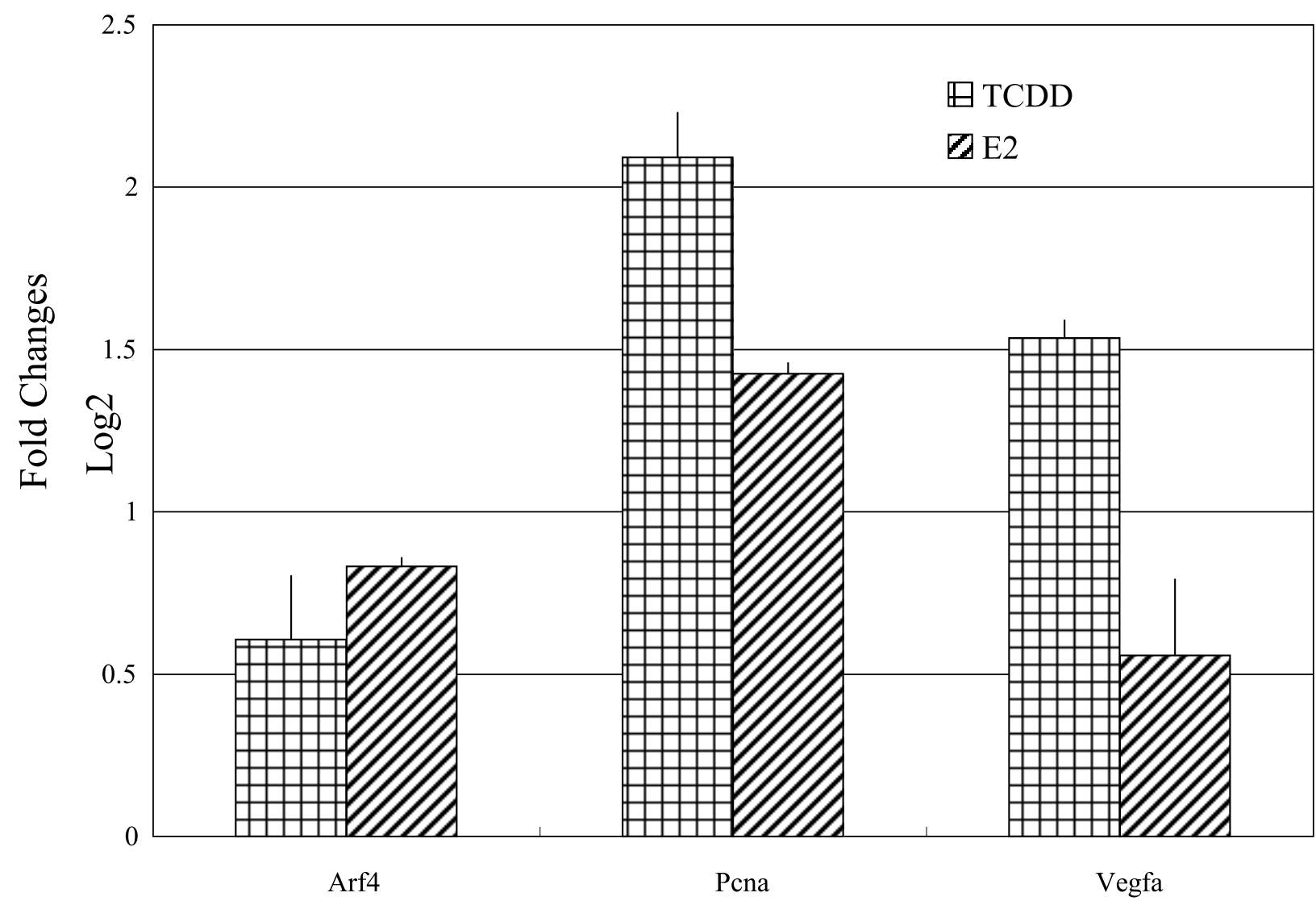

Figure 4 Confirmation of gene activation by either TCDD or estradiol (E2). According to the DNA microarray analysis, genes commonly activated by TCDD and estradiol were selected, and their expression was confirmed by quantitative PCR. Expression levels were normalized to the expression of ribosomal L8 protein gene, and the calculated changes are indicated.

was rather restricted compared with estrogenaffected genes (Watanabe et al. 2002, 2003). Several hundred genes were affected by estrogen treatment, whereas a high dose of TCDD affected only 120 genes, of which 48 were known genes. CYP1A1 was induced in a TCDD dose-dependent manner (Sadek \& Allen-Hoffmann 1994), and AhR repressor (AhRR) (Mimura et al. 1999) was also activated, indicating that the doses in the present study were within the AhR-effective range. Previous studies have demonstrated that cytochrome P450 1Al gene and AhRR are activated via $A h R$ in various tissues and cultured cells (Mimura et al. 1999, Whitlock 1999). These genes are also activated in the uterus. Although several connexin genes are downregulated in the liver in response to TCDD, in our study, connexin 26 gene (M81445) was activated in the mouse uterus.
In addition to the genes showing dose-dependent activation, such as CYP1A1, many TCDD-affected genes were not activated dose-dependently. The genes that were equally activated at either dose might reach an induction plateau by $1 \mu \mathrm{g} / \mathrm{kg}$ TCDD; thus, the expression levels remain constant even at the higher dose. Likewise, other transcription factors may contribute to gene activation. For example, Cyp3A gene is activated by both SXR (Rosenfeld et al. 2003) and TCDD.

Of the genes repressed by TCDD, those related to immunoglobulin were not affected by estradiol. Several studies have described the effects of TCDD on the immune system (Baccarelli et al. 2002) and suppression of NF- $\mathrm{KB}$ activity (Tian et al. 1999). Since NF- $\kappa \mathrm{B}$ affects immunoglobulin gene expression, repression of the genes related to immunoglobulin may be related to the adverse effects of 

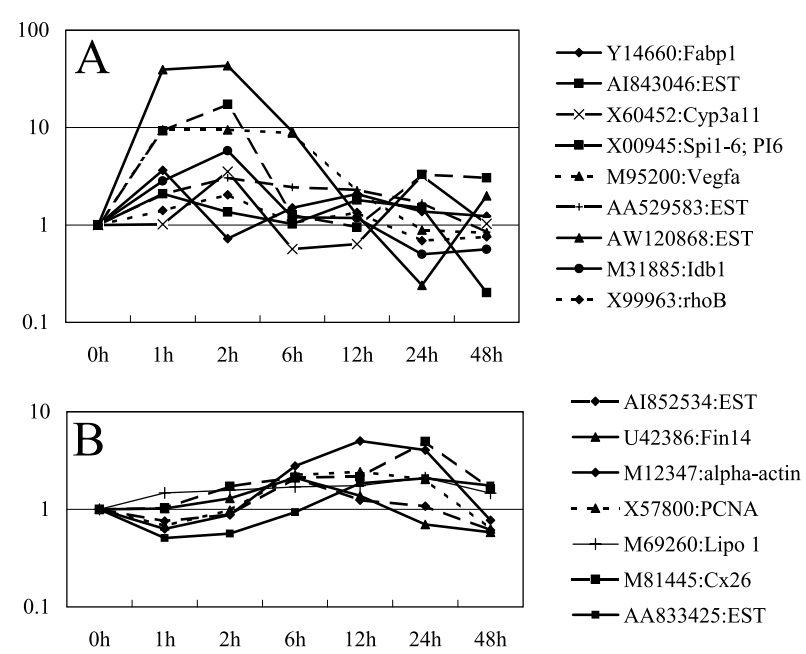

Figure 5 Temporal changes in the selected genes after estrogen treatment. The genes that were induced more than twofold by TCDD treatment were selected, and their expression levels after estrogen treatment were examined. The genes that showed greater changes in response to estradiol at $1-2 \mathrm{~h}$ are indicated in panel $\mathrm{A}$, and the genes that showed greater changes in response to estradiol at 6-48 $\mathrm{h}$ are indicated in panel B. The remaining genes were not activated more than twofold by estradiol at any time point.

TCDD on the immune system. Alternatively, the number of immune cells that migrate to the uterus may be reduced after TCDD treatment.

\section{TCDD and E2-induced genes}

Proliferating cell nuclear antigen (Pcna) and vascular endothelial growth factor (Vegf) were commonly activated by TCDD and E2. Theoretically, if Vegf and Pcna were activated by the estrogenic activity of TCDD, other genes that were efficiently activated by estrogen should be activated by TCDD. Since not all genes activated by estradiol were activated by TCDD, this suggests that TCDD has only partial estrogenic activity. In this context, a clearer understanding of the Vegf gene activation mechanism in response to either TCDD or estradiol may provide important information on TCDD's genetic effects.

Our DNA microarray analysis indicated that only a portion of the estrogen-activated genes (cluster A in Fig. 3) was activated by TCDD, and a larger number of genes were not activated (cluster $\mathrm{B}$ in Fig. 3). Two models have been proposed to explain the estrogenic effects of TCDD. The first focuses on the induction of ER by TCDD (Nesaretnam 1996), and the second model, based on a study of 3-methylcholanthrene, suggests a direct interaction between $\mathrm{AhR}$ and ER (Ohtake 2003). Although our data do not directly support these models, it can be concluded that the estrogenic effects of TCDD in vivo are very limited and that TCDD mimics estrogen only under very restricted conditions in the uterus. Because AhR and ER exhibit very similar distribution throughout the uterus (Fig. 1), the partial estrogenic activity of TCDD may not be related to the tissue-specific distribution of these receptors in the uterus.

In summary, we examined the effects of TCDD on uterine gene expression and demonstrated only weak estrogenic activity. A better understanding of the genes that are activated by both TCDD and estrogen will contribute to a more complete understanding of TCDD's effects on the uterus.

\section{Acknowledgements}

This study was supported by grants from the Japanese Ministry of Education, Culture, Sports, Science and Technology; the Japanese Ministry of the Environment; the New Energy and Industrial Technology Development Organization; Core Research for Evolution Science and Technology and Japan Science and Technology Corporation.

\section{References}

Abdelrahim M, Smith R 3rd \& Safe S 2003 Aryl hydrocarbon receptor gene silencing with small inhibitory RNA differentially modulates Ah-responsiveness in MCF-7 and HepG2 cancer cells. Molecular Pharmacology 63 1373-1381.

Baccarelli A, Mocarelli P, Patterson DG Jr, Bonzini M, Pesatori AC, Caporaso N \& Landi MT 2002 Immunologic effects of dioxin: new results from Seveso and comparison with other studies. Environmental Health Perspectives 110 1169-1173.

Bertazzi PA, Consonni D, Bachetti S, Rubagotti M, Baccarelli A, Zocchetti C \& Pesatori AC 2001 Health effects of dioxin exposure: a 20-year mortality study. American Fournal of Epidemiology 153 1031-1044.

Bois FY \& Eskenazi B 1994 Possible risk of endometriosis for Seveso, Italy, residents: an assessment of exposure to dioxin. Environmental Health Perspectives 102 476-477.

Brown NM, Manzolillo PA, Zhang JX, Wang J \& Lamartiniere CA 1998 Prenatal TCDD and predisposition to mammary cancer in the rat. Carcinogenesis 19 1623-1629.

Cummings AM, Metcalf JL \& Birnbaum L 1996 Promotion of endometriosis by $2,3,7,8$-tetrachlorodibenzo- $p$-dioxin in rats and mice: time-dose dependence and species comparison. Toxicology and Applied Pharmacology 138 131-139. 
Gallo MA, Hesse EJ, Macdonald GJ \& Umbreit TH 1986 Interactive effects of estradiol and 2,3,7,8-tetrachlorodibenzo- $p$-dioxin on hepatic cytochrome P-450 and mouse uterus. Toxicology Letters 32 123-132.

Gibbons A 1993 Dioxin tied to endometriosis. Science 2621373.

Gierthy JF, Lincoln DW, Gillespie MB, Seeger JI, Martinez HL, Dickerman HW \& Kumar SA 1987 Suppression of estrogen-regulated extracellular tissue plasminogen activator activity of MCF-7 cells by 2,3,7,8-tetrachlorodibenzo- $p$-dioxin. Cancer Research 47 6198-6203.

Kim SW, Hayashi M, Lo JF, Yang Y, Yoo JS \& Lee JD 2003 ADP-ribosylation factor 4 small GTPase mediates epidermal growth factor receptor-dependent phospholipase D2 activation. Fournal of Biological Chemistry 278 2661-2668.

Kociba RJ, Keyes DG, Beyer JE, Carreon RM, Wade CE, Dittenber DA, Kalnins RP, Frauson LE, Park GN, Barnard SD, Hummel RA \& Humiston GG 1978 Results of a two-year chronic toxicity and oncogenicity study of 2,3,7,8-tetrachlorodibenzo-pdioxin in rats. Toxicology and Applied Pharmacology 46 279-303.

Krishnan V, Porter W, Santostefano M, Wang X \& Safe S 1995 Molecular mechanism of inhibition of estrogen-induced cathepsin $\mathrm{D}$ gene expression by 2,3,7,8-tetrachlorodibenzo- $p$-dioxin (TCDD in MCF-7 cells. Molecular and Cellular Biology 15 6710-6719.

Li C \& Wong WH 2001 Model-based analysis of oligonucleotide arrays: expression index computation and outlier detection. PNAS $9831-36$.

Manz A, Berger J, Dwyer JH, Flesch-Janys D, Nagel S \& Waltsgott H 1991 Cancer mortality among workers in chemical plant contaminated with dioxin. Lancet 338 959-964.

Mayani A, Barel S, Soback S \& Almagor M 1997 Dioxin concentrations in women with endometriosis. Human Reproduction 12 373-375.

Mimura J, Ema M, Sogawa K \& Fujii-Kuriyama Y 1999 Identification of a novel mechanism of regulation of $\mathrm{Ah}$ (dioxin) receptor function. Genes and Development 13 20-25.

Nesaretnam K, Corcoran D, Dils RR \& Darbre P 1996 $3,4,3^{\prime}, 4^{\prime}$-Tetrachlorobiphenyl acts as an estrogen in vitro and in vivo. Molecular Endocrinology 10 923-936.

Ohtake F, Takeyama K, Matsumoto T, Kitagawa H, Yamamoto Y, Nohara K, Tohyama C, Krust A, Mimura J, Chambon P, Yanagisawa J, Fujii-Kuriyama Y \& Kato S 2003 Modulation of oestrogen receptor signalling by association with the activated dioxin receptor. Nature 423 545-550.

Rier S \& Foster WG 2002 Environmental dioxins and endometriosis. Toxicological Sciences 70 161-170.
Rier SE, Martin DC, Bowman RE, Dmowski WP \& Becker JL 1993 Endometriosis in rhesus monkeys (Macaca mulatta) following chronic exposure to 2,3,7,8-tetrachlorodibenzo- $p$-dioxin. Fundamental and Applied Toxicology 21 433-441.

Romkes M, Piskorska-Pliszczynska J \& Safe S 1987 Effects of 2,3,7,8-tetrachlorodibenzo- $p$-dioxin on hepatic and uterine estrogen receptor levels in rats. Toxicology and Applied Pharmacology 87 306-314.

Rosenfeld JM, Vargas R Jr, Xie W \& Evans RM 2003 Genetic profiling defines the xenobiotic gene network controlled by the nuclear receptor pregnane X receptor. Molecular Endocrinology 17 $1268-1282$.

Sadek CM \& Allen-Hoffmann BL 1994 Suspension-mediated induction of Hepa 1clc7 Cypla-1 expression is dependent on the Ah receptor signal transduction pathway. Fournal of Biological Chemistry 269 31505-31509.

Safe S, Astroff B, Harris M, Zacharewski T, Dickerson R, Romkes M \& Biegel L 1991 2,3,7,8-Tetrachlorodibenzo- $p$-dioxin (TCDD) and related compounds as antioestrogens: characterization and mechanism of action. Pharmacology and Toxicology 69 400-409.

Tian Y, Ke S, Denison MS, Rabson AB \& Gallo MA 1999 $\mathrm{Ah}$ receptor and NF-kappaB interactions, a potential mechanism for dioxin toxicity. Fournal of Biological Chemistry $\mathbf{2 7 4}$ $510-515$.

Watanabe H, Suzuki A, Mizutani T, Khono S, Lubahn DB, Handa H \& Iguchi T 2002 Genome-wide analysis of changes in early gene expression induced by oestrogen. Genes to Cells $\mathbf{7}$ 497-507.

Watanabe H, Suzuki A, Kobayashi M, Takahashi E, Itamoto M, Lubahn DB, Handa H \& Iguchi T 2003 Analysis of temporal changes in the expression of estrogen-regulated genes in the uterus. Fournal of Molecular Endocrinology 30 347-358.

Whitlock JP Jr 1999 Induction of cytochrome P4501A1. Annual Review of Pharmacology and Toxicology 39 103-125.

Wormke M, Stoner M, Saville B, Walker K, Abdelrahim M, Burghardt R \& Safe S 2003 The aryl hydrocarbon receptor mediates degradation of estrogen receptor alpha through activation of proteasomes. Molecular and Cellular Biology $\mathbf{2 3}$ 1843-1855.

Received 12 July 2004

Accepted 12 August 2004 